\title{
Slight Productions: An Introduction to Maria Edgeworth's Comic Dramas (1817)
}

\section{Carmen María Fernández-Rodríguez}

EOI Santiago de Compostela, Spain

Copyright (c) 2012 by Carmen María Fernández-Rodríguez. This text may be archived and redistributed both in electronic form and in hard copy, provided that the author and journal are properly cited and no fee is charged for access.

\begin{abstract}
Most studies on Maria Edgeworth's oeuvre are centred on her Irish tales. Despite the growing interest in this woman writer, there is no research on her amateur theatricals. After a brief contextualisation of Edgeworth and the stage, this paper aims to describe and highlight the main features of Comic Dramas (1817), one of Edgeworth's lesser productions. The volume includes three pieces (Love and Law; The Two Guardians and The Rose, Thistle and Shamrock) which are set in Ireland and England. Apart from the presence of issues from her tales and educational manuals, what interests us here is that, far from upholding Anglicisation, the Anglo-Irish authoress defends community and an integrating British nation. Comic Dramas is admittedly tinctured by sentimentalism and social critique. For this reason, the examination of these pieces cannot be neglected to obtain a comprehensive panorama of Edgeworth's vision of Ireland.
\end{abstract}

Key Words. Maria Edgeworth, Ireland, theatre, women's literature, colonialism.

Resumen. La mayoría de los estudios sobre la obra de Maria Edgeworth se centran en sus relatos irlandeses. A pesar del creciente interés en esta escritora, carecemos de estudios sobre sus obras de teatro amateur. Tras una breve contextualización sobre Edgeworth y la escena, este trabajo pretende describir y enfatizar las características principales de Comic Dramas (1817), una de las producciones menores de Edgeworth. El volumen incluye tres obras (Love and Law; The Two Guardians y The Rose, Thistle and Shamrock) que se desarrollan en Irlanda e Inglaterra. Además de la presencia de temas de sus relatos y manuales educativos, lo que nos interesa aquí es que, lejos de defender la anglicización, la autora angloirlandesa defiende la comunidad y nación británica integradora. Comic Dramas está indiscutiblemente teñido de sentimentalismo y crítica social. Por este motivo, el examen de estas obras no puede obviarse para obtener una panorámica completa de la visión que Edgeworth tenía de Irlanda.

Palabras clave. Maria Edgeworth, Irlanda, teatro, literatura escrita por mujeres, colonialismo.

\section{Introduction}

Maria Edgeworth (1768-1849) is currently undergoing an explosive revival. In the 1990s, feminist scholars began to study her novels of manners (Kowaleski-Wallace 1991, Gallagher 1994 and Bilger 1998), several dissertation theses were published on Edgeworth's Irish production (Connolly 1998 and Kilfeather 1989) and some valuable criticism appeared in the realm of postcolonial studies (Perera 1991 and McLoughlin 2002). In Spain, the translation into Spanish of some of Edgeworth's 
most successful stories saw the light (Edgeworth 2000 and 2004), as well as a biography of the Edgeworths (Barbé i Durán 2002). Regarding scholarship, interest has focused on the parallelisms between the political situation in Ireland and the marital crises in Castle Rackrent (González 1994), the contrast between Thady's vernacular language and the voice of the writer in the guise of editor (Andreu 2005) and the translation of Edgeworth's works into French and German (Fernández 2008 and 2010a). However, it is amazing to observe that there is scarcely any study on the dramatic production of the founder of the Anglo-Irish novel and the socalled "Big House Novel" and scholarship still obsessively revolves around Edgeworth's regional novels. We will try to offer an introduction to Edgeworth's theatre by focussing on the unexplored Comic Dramas in Three Acts (1817). The volume, which was neither translated nor published on the continent, includes three pieces (Love and Law; The Two Guardians and The Rose, Thistle and Shamrock) and appeared when Edgeworth had already achieved a consolidated position as an authoress after the success of Patronage (1814) and Harrington (1817) and just some days before Richard Lovell's death. At that time, Maria was struggling to complete Ormond, and she would be retired from the literary world until the publication of Continuation of Harry and Lucy (1824), Helen (1834), and later, during the Irish Famine, Orlandino (1848). Here we aim to advance some points of the social and political critique contained in these comedies through a description of the main features and interrelated topics which can be usefully explored by referring to Homi K. Bhabha's work on colonial stereotypes and to some conventions on the British stage in that period. Writing on eighteenth-century drama, John Loftis argues that Georgian playwrights largely ignored both social dislocations and the sufferings of persons of lower rank at the same time that they kept as silent about political controversy as about economic deprivation. Drama concentrated on personal and domestic concerns; and, whereas the relation between the sexes was important, the exploration of sexual passion was impeded by the custom on the stage (1977: 18-33). Therefore, Loftis labels late eighteenth-century comedies as bland because they took a genial and optimistic view of the human condition and avoided disturbing issues. Such a categorisation can, perhaps, be applied to Sheridan's and Murphy's productions, but not to Edgeworth's plays which, as we will see, touch on all social levels rather than confining themselves to a particular class or place and become a critique of colonialism and patriarchal power. Additionally, it is interesting to revise the validity of the last part of Marilyn Butler's statement when she distinguishes between the "Irish Tales" in Tales of Fashionable Life (first and second series 1809, 1812) and lesser works, such as Comic Dramas, Rosanna and Double Disguise (Popular Tales, 1804): "none of these popular works deal with Irish life in the same detail, or as broadly, as the longer and intellectually more ambitious tales for Maria's own class; they carry no weight as political statements about Ireland" (1972: 125, my italics). Though this is not the place to undertake a comparison with the Irish tales, Comic Dramas is definitely worthy of study and reveals Edgeworth's ambiguous position towards Ireland as a colonised territory.

\section{Edgeworth and the theatre}

Any research on Edgeworth must inevitably start from the work of Marilyn Butler, who has written numerous articles and an excellent biography on the Anglo-Irish authoress. In her edition of Edgeworth's oeuvre for Pickering and Chatto (1999-2003), Butler only includes the comedy Whim for Whim (1798), leaving Comic Dramas and dramatic productions for children (Old Poz,1800), The Orange Woman and The Organ Grinder (c. 1808) aside. Critical neglect of Edgeworth's theatre can be attributed to two factors. On the one hand, Richard B. Sheridan had rejected an early dramatic version of The Absentee because the Irish subject would not be suitable for the London stage. The scarcity of actors for the Irish roles and the reaction of the audience would have made performance difficult (Butler 1972: 277) though George Farquhar, Oliver Goldsmith and Sheridan had introduced prototypical characters in their comedies. When Edgeworth finally published these plays, she was aware that they could be performed before Dubliners and Londoners who were detached from the Irish reality. Not coincidentally, George III exclaimed after 
reading Castle Rackrent that he got to know his Irish subjects at last (Cronin 1980: 25).

On the other hand, Maria was not confident of her output (Butler 1972: 278-9), and her father called Comic Dramas "slight productions" (qtd. Butler 1972: 301). In a letter to Elizabeth Inchbald dated 21 May 1817, Richard Lovell explained that Comic Dramas "were intended for the closet, \& not for the stage" (Slade 1937: 165). He also predicted the fate of each play ("if actors could be procured for it would be Love \& Law - that which will be the most popular is the Rose, thistle \& Shamrock - but the best writing by far, is the two guardians" [Slade 1937: 165]), and he added about the latter: "If there were one striking Comic character introduced into the Two Guardians, \& if some of Mr. Onslow's wisdom \& morality were curtailed, something might be made of this play, for I think it is well written" (Slade 1937: 165). Maria's doubts are also connected with her gender despite the long tradition of women's drama that went back through Hannah More and Hannah Cowley to writers such as Charlotte Lennox, Frances Sheridan, Eliza Haywood, Susanna Centlivre, Delarivière Manley and Aphra Behn. Kitty Clive, Frances Sheridan, Charlotte Lennox and Dorothy Celisia were some of the women dramatist contemporary of David Garrick, George Colman and Richard Cumberland. Nevertheless, a woman who turned her own gaze back on a society that objectified women was actively deconstructing the authority it claimed to have, and the theatre was a suspect choice for a proper lady. The prestigious novelist Frances Burney was warned by her tutors that "In the Novel Way, there [was] no Danger" (qtd. in Doody 1988: 96), and Charles Crisp had insisted "I will never allow You to sacrifice a Grain of female delicacy, for all the Wilt of a Congreve \& Vanbrugh put together" (qtd. in Chisholm 1998: 84). Eventually, she preferred novel writing to endangering her reputation. Prologues, epilogues and prefaces signed by influential male friends are a characteristic of drama by women and Richard Lovell Edgeworth pens the preface to Comic Dramas. After stressing the simplicity of the plays, he distinguishes between a tale and a comedy: while in the former "there is room for detail of small circumstances, and for that gradual development of sentiments and incident, which make us acquainted with the persons whose adventures are related, and which insensibly interest us in the fable" (Edgeworth 1817: vi), in the latter "the characters must be shewn [sic] by strong and sudden lights, the sentiments must be condensed; and nothing that requires slow reflection can be admitted. - The audience must see, hear, feel and understand at once" (Edgeworth 1817: vi).

Like Little Plays for Children (1827), Comic Dramas was planned as a collection of home theatricals (Butler 1972: 165) encapsulating Edgeworth's dramatic genius. Yet, the volume represents a technical handicap: a narrative allows a more complex analysis of the forces motivating the characters' actions and their development, as well as the possibility to introduce social classes and their circumstances in detail, and this was precisely Edgeworth's strong point. The dramatic writer had to be more selective, as the actress Elizabeth Inchbald pointed out in her "Remarks" prefacing the 125 works in The British Theatre (1806-9): a play will always get more favour with a reader than a spectator because the imagination gives graces, charms and majesty which their representatives cannot always bestow. Besides, more is described to the audience than happens on stage (Backschreider, Paula 2007: 87). Two of the pieces in Comic Dramas are very close to Castle Rackrent regarding characters, style and themes. Similarly, it is very easy to find parallelisms with Ormond and Patronage, and reviewers even suggested that Comic Dramas should be retitled "Dramatic Narratives" since they "have little in them adapted to the stage" (The British Critic 1817: 513). Structurally the plays contain three acts with a number of scenes ranging from one to four. Characters are defined by their discourse and the main spaces are domestic ones. Some common features are the love plot - though in The Two Guardians love is not prominent - and the positive vision of the Anglo-Irish while the Catholics are characterised by their brogue, Gaelicisms and tendency to duelling.

According to Christopher J. Wheatley; in terms of subject-matter and generic conventions, Irish dramatists wrote plays distinctly different from those produced in London (1995: 2), and Edgeworth's plays have an indistinguishable Irish flavour. In the opening years of the nineteenth century, Irish 
theatrical life shone and Dublin even was home to The Theatrical Magazine. Moreover, there were demands for Irish material on Irish stages (Morash 2002: 76, 82), where stereotypes existed. In Bhabha's terms, stereotypes are related to the ambivalence of colonial discourse which is characterised by processes of iteration and translation erasing any claims for the inherent authenticity or purity of cultures. These false images help to justify conquest thanks to the perception of the colonised as degenerate types on the basis of racial origin (1994: 70). When Edgeworth, the uncomfortable authority - as she is called in Kauffmann and Fauske's anthology -, faced the Irish reality, she was trapped in the ambivalence pointed out by Robert Tracy: aware of the Ascendancy's failure to put down roots in Ireland and to evoke loyalty from the Irish, she was impelled to an endorsement of Irish tradition and Irish identity at the same time that paternal principles made her deny such an endorsement (1998: 9). Edgeworth's biographer has already stressed that the family was fascinated by the rural Catholic peasantry and tenantry, and the authoresses identified the Irish nation as a cultural formation with very strong local roots, the village and land, surrounded by the region or a province (Butler 2004: 48). Drama might have appeared to her as a subaltern site, a space in the Irish colonial past which was capable of bringing into being new, non-English states of culture and practice through acts which subverted and estranged the dominant cultural script. As we will see, satire proved to be a suitable instrument to condemn certain attitudes towards the Irish, women, education and the low classes.

\section{Love, education and the Empire.}

Marriage was one of the prevalent metaphors to represent the complicate interaction between England and its possessions in the British Isles. Love and Law deals with the relationship between Protestant Honor McBride and Catholic Randal Rooney whose families have been long quarrelling for the property of the bog of Ballynascraw now in the hands of Catty Rooney, Randal's proud mother. As Matthew Arnold pointed out (On the Study of Celtic Literature, 1867; Irish Essays, 1882), Ireland was systematically envisioned as a woman while England was seen as male. The Irish fortune hunter, a recurrent figure in Charles
Macklin's and Sheridan's comedies, symbolised the menace that the Gaelic Catholic nobility might recover the power they had lost. Seducing an heiress or obliging one to marry were some of the strategies to regain such influence. In John O'Keeffe's The Poor Soldier (1783), the protagonist is granted a commission and the hand of his sweetheart which stands for the Irish Catholics' longed-for recovery of place in the Irish political nation. Other precedents also portrayed the marriage of the New English, such as Charles Shadwell's Irish Hospitality (c.1718); and Macklin's The True Born Irishman (1761) is about the restoration of the Irish Catholic Nation. Both in Love and Law and The Rose, there is a coded subtext where women are important and related to Irish sovereignty. In the same way that Grace Nugent bears a highly symbolic name in The Absentee (Maguire 1996), in Love and Law there are two women directly linked with Ireland. One of them is Honor McBride whose dowry is coveted by O'Blaney ands who is significantly employed by the representatives of the Ascendancy, the Carvers, as a servant willing to leave her home - and thus to sacrifice herself and to be dispossessed - to prevent a fight between her brother Phil and O’Blaney.

Edgeworth insists on the need to connect the Anglo-Irish order with the old Irish tradition, and, in Comic Dramas, the domestic level parallels the national one. In Edgeworth's stories - Castle Rackrent, for instance - the property that had formerly belonged to Protestant landowners passes into the hands of Catholic characters and the mechanism of transfer is marriage, which effects the alliance between native and settler cultures. In Love and Law, the McBrides are the descendants of the Scots who arrived in Ireland in Cromwell's times while the Rooneys are one of the oldest Irish families. Through her name, Randal's mother is directly related to Cathleen $\mathrm{Ni}^{\prime}$ Houlihan, a legendary figure echoing the dispossession of the Irish and evoked by William B. Yeats (The Countess Cathleen, 1892; Cathleen Ní Houlihan, 1902 in collaboration with Lady Gregory) and described in songs and poems as a beautiful maiden who is alone, defenceless and robbed of her rightful inheritance until a husband rescues her, restores her lands and fathers strong children upon her. Catty's insults 
towards the McBrides are full of political connotations and reveal her resentment towards a wealthy élite:

Catty. [...] What are they? Cromwellians at the best. - Mac Brides! - Macks - Scotch! not Irish native - at-all-at-all. - People of yesterday, graziers and mushrooms (mushrooms) - which tho' they've made the money, can't buy the blood. - My anshestors sat on a throne, when the M'Brides had only their hunkers to sit upon; and if I walk now when they ride, they can't look down upon me for every body knows who I am - and what they are (Edgeworth 1817: 45-6).

In Sheridan and Macklin, female desire is underrated, but, in Love and Law, Old McBride sanctions her daughter's choice (Edgeworth 1817: 58-9). Mr. Gerard O'Blaney, the owner of a distillery, wants to marry Honor, and he tells his servant, Pat Cox, to injure her reputation all around the village. When the truth is discovered, Catty admits that if she does not accept Honor, it is not because of her conduct: " "twas only for pride I stood out - not that I'm thinking of now!'” (Edgeworth 1817: 129). Eventually, Catty recovers the bog before the moral arbiter at the climax, Magistrate Carver, who is identifiable with Richard Lovell Edgeworth (Butler 1972: 247), because Honor asks his father to return it to the Rooneys.

The Rose, the Thistle and the Shamrock, is about a new inn promoted by Miss Clara O'Hara, Sir William Hamden's niece and heiress. Both Gilbert, an English servant who is secretly in love with Mabel Larken, Widow Larken's daughter, and the Larkens want to obtain this establishment. Unfortunately, Clara, "'that warm Irish heart"” (Edgeworth 1817: 310), irresponsibly grants it to Mr. Gallagher. As soon as Sir William hears the news, he moralises on the importance of knowing how to do good. He also advises Clara to finish her projects and to avoid making verbal promises to tenants (Edgeworth 1817: 312). Fortunately Gilberts obtains the inn after several incidents and marries Mabel. In The Rose, Gilbert uses a floral metaphor to discover Mabel's feelings. Edgeworth's heroines conform to the domestic ideal. Far from being women of ideas, protagonists exemplified the paradigm outlined by Mary Poovey (1984) or Nancy Armstrong (1987). The song that Gilbert sings stands for a rejection of ladies and affirms Irish women's sweetness and superiority in conservative terms:

Gilbert. There's none but a fool will wed on a sudden, Or take a fine miss that can't make a pudding; If he get such a wife, what would a man gain, $\mathrm{O}$ ? But a few ballad tunes on a wretched piano Some ladies than peacocks are twenty times prouder, Some ladies than thunder are twenty times louder; But I'll have a wife that's obliging and civil, For me, your fine ladies may go to the devil (Edgeworth 1817: 350-1).

One of the traits of Edgeworth's writing is its cosmopolitanism and the incorporation of non-British nationalities (Fernández 2009). For this reason, she may be suitably called a novelist of the Empire, even of the Union. John O'Keeffe's The Shamrock; or St. Patrick's Day (1777) concluded with a pageant in which the different ethnic groups and cultures which had historically opposed each other in Ireland Native Irish, Anglo-Normans, Danes and Hibernians - all matched together in a show of unity. In The Rose, there are constant references to the political situation in Ireland at different levels. The three flowers picked up by Gilbert symbolise the three nationalities who have joined to obtain the inn, a metaphor of the Union (Edgeworth 1817: 351) also featured in "Bath Coach Conversation" (Essay on Irish Bulls, 1802). Gilbert describes the Gallaghers' inn as an example of abandonment and misrule, an epitome of Ireland, while Sir William struggles to convince him that the Irish are good people: "[...] there's a pig in and out of the kitchen all day long, and next the calf has what they call the run of the kitchen [...] the kitchen is no place for a Christian, and even to eat his bread and cheese in" (Edgeworth 1817: 263-4). The Two Guardians contains a rich diversity of cultures, as well: a German music professor (Professor Van Lichenschwartz), a French master (M. Le Grand, who teaches the ballet and the quadrille) and a black boy appear. On the other hand, Mrs. St. Albans recalls Virginia St. Pierre in Belinda in the sense that both are Creole, generous and affectionate; and $\mathrm{Mr}$. Vincent opposes Belinda to West Indian women who are "“all softness, grace, delicacy”” (Edgeworth 1994: 233) and whose indolence is an amiable defect: "'it keeps them out of mischief, and it attaches them to domestic life"” (Edgeworth 1994: 233). Mr. Osnlow notices Mrs. St. Albans's weak character and 
advises her to "'have the strength of mind to prefer the right to the expedient'" and to avoid ruining St. Albans (Edgeworth 1817: 209).

While Love and Law and The Rose are very close to the stories in Popular Tales, The Two Guardians can be appropriately inserted in the tradition of the comedy of manners and even the pedagogical essay. It criticises the high classes and, curiously, it does not deal either with womanisers or witty woman. Sympathy and personal integrity come to the fore. In The Two Guardians, Mr. Onslow and Lord Courtington - a name which clearly resembles Delacour in Belinda - are appointed the guardians of St. Albans, a young gentleman who has recently arrived from the West Indies accompanied by his mother and her faithful black servant Quaco - bearing the same name as the slave in Whim for Whim.

Education is a recurrent topic in Edgeworth, who fictionalised the principles contained in Practical Education in her tales and novels. However, as we will see, Edgeworth's intellectualism is not as prominent as in other productions containing a good deal of erudite references. The Two Guardians opposes the ideology of the old generation and the young people at different levels. The Courtingtons' insensibility contrasts with the Onslows' common sense. While Lady Courtington favours the city and states that everything depends on the boy's tutor (Edgeworth 1817: 198), Mr. Onslow maintains that character is gradually formed, friends do not have to be necessarily fashionable and in the city there are many temptations for young people. In this scene - a French scene in Onslow's words (Edgeworth 1817: 208) - , Mrs. St. Albans faints and Mr. Onslow satirically comments that he is simply "'a poor country gentleman, who sees every thing en noir'” (Edgeworth 1817: 208). According to Butler, Edgeworth did not like the absence of realism or humanity in depicting the lower orders of society in French theatre, and she would focus on the middle and lower classes (1972: 151). We will see that Edgeworth's oeuvre is populated with black characters imbued with humanity and, in The Two Guardians, Quaco's main merit is his generosity towards St. Albans paralleling the spirit of sacrifice characterising the Irish.

\section{Liberal views and social insensibility}

There is no consensus on whether Edgeworth was an abolitionist or not. According to Catherine Burroughs, Edgeworth created plots that represented a strange mixture of antislavery sentiments and racist attitudes, as Hannah Colley did (2000: 5). After explaining that antislavery, sentimentalism and freelabour thought were the offspring of capitalist and bourgeois ideology; Boulukos analyses the tale "The Grateful Negro" (Popular Tales) inspired on Bryan Edwards' History, Civil and Commercial, of the British Colonies in the West Indies (1798) and demonstrates how sentimental discourse aided slavery's apologists. According to Alison Harvey; in Castle Rackrent, Ennui, Essay on Irish Bulls, "The Grateful Negro" and The Two Guardians; Edgeworth blurs the conventional views of gender and race and offers a critique of the hegemonic power assumed by the white English patriarchal society (2006: 2). This scholar argues that there is no gap between Quaco's modified form of slavery as willing servitude and the legal freedom (2006: 16). In Edgeworth's Irish works, the Irish can be easily associated with the dependant colonised desirous to speak his own identity, as O'Shaughnessy maintains in an article about Castle Rackrent (1999: 430-1, see also Fernández 2010b: 278-9). Edgeworth joins other female dramatists at the end of the eighteenth century who promoted the rights of the disenfranchised and composes one story about slavery for Comic Dramas.

Many plays of the period included black characters: from Isaac Bickerstaffe's The Padlock (1768), they had become comic figures on the London stage. William Macready's The Irishman in London; or, The Happy African (1792), Archibald McLaren's The Negro Slaves; or, The Blackman and the Blackbird (1799) also dealt with blacks, who usually appear within a love/marriage plot in abolitionist literature. One of Maria's friends, the authorial performer Elizabeth Inchbald reflected a troubled nationalism in her works The Mogul Tale (1784), Such Things Are (1787) and The Wise Man of the East (1799).

Drama meant the possibility to question uncomfortable issues about sex and power in English society. In the same way that the English novelists in the eighteenth and nineteenth centuries created feminine and feminist strategies to address social injustice, female playwrights could mock the powerful and 
debate cultural assumptions from the stage, a significant circumstance which is ignored in traditional analysis, such as Loftis's one. As Catherine Burroughs points out, social comedy allowed female authors to participate in topical debates without alienating those audiences who would be resistant to the idea of an unfeminine, that is, politically serious, woman writer (2000: 4). Edgeworth takes advantage of this genre to vindicate social justice. In Whim for Whim, Quaco is freed from slavery by Opal and is brought to England where there are no slaves. Like in "The Grateful Negro", Quaco accepts his slavery by internalising a paternalistic sentimental contract and faces incomprehension (Edgeworth 1817: 14). If in Whim for Whim Félix hates Quaco, in The Two Guardians Quaco is insulted by Blagrave and Beaufort:

Bla. [...] there's no managing them blacks, nor breeding 'em to have the sense or memory of a Christian, without flogging of it into them, they say; on account they've not the feeling we have.

Beau. (Walking up and down, fretting and swearing.) $\mathrm{C}$ - se it! Confound 'em all in one bag; - so I'm to lose my gallop! - and between blacks, and guardians, and quadrilles, and hysterics, we sha'n't get St. Albans out this day [...] (Edgeworth 1817: 210-11).

For Juliana, “'Negroes are all naturally inferior"” (Edgeworth 1817: 234); however, in Edgeworth's comedy, the blacks and women are far more sympathetic than the rich. St. Albans gives Quaco a little scarlet purse with the money he has earned and something more so that " "[he] should not lose the value of [his] former labour"” (Edgeworth 1817: 161). His master just wants to be shown that Quaco is a reasonable being and fit to be free. Quaco mimicks his master's behaviour: not only does he offer Mrs. Beauchamp a glass of water and pities her (Edgeworth 1817: 186), but he also gives her his purse and warns St. Albans about Juliana: " "take you care! take you care! - she no love, she never, no never, love like Massa!"” (Edgeworth 1817: 246). The black servant colonised for his race is related to the poor widow colonised for her sex since Mrs. Beauchamps takes care of St. Albans after a fall from his horse, and the young man realises that Quaco's generosity towards Mrs. Beauchamps - to whom he had anonymously lent money - is more valuable than the ridiculous efforts of Miss Juliana, Lady Courtington's daughter, to conquer his heart. The defence of freedom and Britishness recalls Whim for Whim. In the later, Quaco is surprised when Felix hints that Opal will free him and defends England: "'Massa Opal took me from de cruel men, and carry me to Englis men's land where be no slaves - Fine country Englan!'” (Edgeworth, 1999-2003, vol. 12: 320-1). Both Quacos cannot envision living without their masters. In England there is "'no slave no where"” (Edgeworth 1817: 160) and Quaco opposes civilised Popkin as long as the former regards his interests as intertwined with his master's.

Sentimental comedy, the genre to which The Two Guardians belongs, was directly related with sentimental fiction and combined domestic settings, morality and humour. The best example is Sir Richard Steele's The Conscious Lovers (1722). In Edgeworth, the masculine protagonist, Mr. St. Albans, is a "man of feeling", and, more than a tear-jerking drama, the play seems a realistic social portrait with some doses of humanitarianism. A recurrent subject at the time was the middleclass anxiety to imitate the well-off. In The Two Guardians, characters know that they inhabit an artificial world where appearances count more than common sense. Marriage held out the promise of sexual fulfilment and social adulthood to women, in spite of the legal and economic inequalities between men and women that marriage and property law reproduced. Therefore, Juliana thinks about her possibilities to get married and to be independent of her family (Edgeworth 1817: 213-4). She perceives herself as " A martyr at all events"” (Edgeworth 1817: 151) and rejects the educational schemes promoted by Lady Courtington: “'except dancing, what woman but lays it all aside as soon as ever she is married?"” (Edgeworth 1817: 153-4). Among the gentry and middle classes, the education of girls was an afterthought. Literacy, a smattering of polite letters and the acquisition of acceptable social graces were the limits of female education, the main concern in Letters for Literary Ladies (1798). While Lady Courtington is attracted by St. Albans's education and gallantry, her daughter is unable to conquer his affection. St. Albans's preference of the song "Sympathy" to "Simplicity" tells much about himself. On the 
other hand, male education was the means of upward social mobility and, in The Rose, Owen had been educated, as Biddy explains " "till the troubles came across his family, and the boy, the child, for it's bare fifteen he is this minute, give up all his hopes and prospects, the cratur! To come home and slave for his mother'” (Edgeworth 1817: 297).

The rich cannot understand the efforts of others to earn their living, which appeared in “The Dun” (Tales of Fashionable Life 1809). If in Love and Law, O'Blaney tries to eschew creditors (Edgeworth 1817: 17), in The Two Guardians, Lady Courtington avoids paying her milliner, her harp teacher and even regrets having recommended him to her acquaintances (Edgeworth 1817: 170-1). Though Widow Beauchamp is Juliana's relative, and, according to Popkins, a gentlewoman born, Juliana tells Popkin to expel her (Edgeworth 1817: 150). When Popkins complains, St. Albans and his mother condemn his attitude: " Accomplishments! - What are they, if truth, if principle have been sacrificed?'” (Edgeworth 1817: 243).

The world of servants - low life above stairs, paraphrasing a well-known anonymous comedy (1759) - is very important in Comic Dramas, where servants unveil the real villains and many characters pretend to be what they are not. Edgeworth makes servants visible to integrate political, economic, moral and domestic issues at the same time that they affirm their vision of a transformative paternalism infused with social rebellion. In Love and Law, the first criticism against the Irish comes from Bloomsbury, Mrs. Carver's servant, who is jealous of Honor and rejects Irish waiting maids to the point that she has been "'forced to stuff [her] hears with cotton wool hever since[she] come to Ireland'” (Edgeworth 1817: 34). In The Two Guardians, Popkin is persuaded that he controls St. Albans and Balgrave and is defined by Mr. Onslow as "'One of those nuisances, called a fine footman, which some foolish fine people are pleased to keep in their houses to insult their guests, waste their fortunes, debase the manners, and corrupt the morals of their children!'” (Edgeworth 1817: 193). Soliloquies and asides establish some complicity with the reader and describe psychology. They function as internal focalisation. A very revealing example appears in Love and Law when Pat finds out that O’Blaney has asked the post Pat wanted for another person:

Pat. Mistake? aye, mistake on purpose - so he never spoke! so he lied! - my master that was praching me! - And oh, the dirty lie he tould me! Now I can't put up with that, when I was almost perjuring myself for him at the time. Of if I don't fit him for this! And he got the place given to another! - then I'll get him as well sarved, and out of this place too - seen if I don't ! He is cunning enough, nut I'm cuter nor he - I have him in my power, so I have; I'll give the shupervishor a scent of the malt in the turf-stack - and a hint of the spirits in the tanpit - and it's I, that will like to stand by innocent, and see how shrunk O'Blaney's double face will look forenent the shupervishor, when all's found out, and not a word left to say, but to pay - ruined hand and foot! Then that shall be, and before nightfall. - Oh! one good turn deserves another - in revenge, prompt payment while you live! (Edgeworth 1817: 734).

It is worth bearing in mind that many of the speeches in Comic Dramas were taken from life as Richard Lovell explained in a letter to Mrs. Inchbald: “Christy Gallagher is a genuine Irish character; so is Kathy Roony; but Biddy Doyle is an original” (qtd. in Butler, 1972: 249). Biddy, a name referring to Irish maids, complains of her situation because the Gallaghers make her work hard and call her "Sheelah na Ghirah", a name commonly associated with the rural Catholic masses:

Biddy.[...] there's not a greater slave than myself in all Connaught, or the three kingdoms, from the time I get up in the morning, and that's afore the flight of night, till I get to my bed again at night, and that's never afore one in the morning. - But I wouldn't value all one pin's point, if it was kind and shivil (civil) she was to me. But after I strive, and strive to the utmost and beyond, - (sighs deeply) and when I found the inions, and took the apple-pie off her hands, and settle her behind, and all to the best of my poor ability for her, after, to go and call me Sheelah na Ghirah! Though I don't rightly know who that Sheelah na Ghirah was, from Adam! But still it's the bad language I get, goes to my heart. - Oh, if it had but plased heaven to have cast me my lot in the sarvice of a raal jantleman or lady, instead of the likes of these! Now, I'd rather be a dog in his honor's or her honor's house, than lie under the tongue of Miss Gallagher, as I do, - to say nothing of ould Christy (Edgeworth 1817: 285). 


\section{Conclusion}

From the ideological point of view, Comic Dramas confirms Edgeworth's unionist temper and support of Britishness. Simultaneously valuing Irish tradition and Irish strangeness, Edgeworth envisions Britain as a commonwealth of nations where the process of miscognition in which coloniser and colonised are engaged in the colonial world ends and is replaced by a humanitarian view of society. Instead of a space confirming the productivity of colonial power, of its shifting forces and fixities, Ireland should be marked by positive inclusiveness, which does not necessarily imply Anglicisation, but the integration of cultures. There is a defence of social justice which does not depart much from that depicted in her Irish tales. Love and Law and The Rose focus on "Irishness" and the hardships endured by the lower classes through the dialogism between standard English and other British dialects. For her representation of all social classes and native speech, Edgeworth must be affiliated with British Romanticism. The role of women, patrimony and the division between Catholics and Protestants are some of the main themes, together with issues, such as race, education and manners. As for the insertion of The Two Guardians in Comic Dramas, it does not seem casual given that Edgeworth mixes the sentimental tone with satire and the suffering of the Irish is transferred to another oppressed community, the blacks. This is perhaps the unifying trait of these comedies, that all readings inevitably converge in a political one. Undoubtedly, Comic Dramas needs to achieve visibility through an annotated reedition. The bicentenary of the second series of Tales of Fashionable Life provides an excellent occasion for such an enterprise. Now the path remains open for a detailed comparison with the Irish tales, some historicist Butler-like research, or a folkloric study to assess more accurately 'or to reformulate' how the Anglo-Irish authoress contributed to the literary creation of Ireland.

\section{Works Cited}

Andreu, Cristina. 2005. "Maria Edgeworth's Irish Novels and the Question of National Identity". Humour and Tragedy in Ireland. Eds. Patricia Trainor de la Cruz and Blanca Krauel Heredia. Málaga: Universidad de Málaga. 123-131.

Armstrong, Nancy. 1987. Desire and Domestic Fiction: a Political Study of the Novel. New York: New York UP.

Bhabha, Homi K. 1994. The Location of Culture. London and New York, Routledge.

Backschreider, Paula R. 2007 "Shadowing Theatrical Change”. Players, Playwrights, Playhouses. Investigating Performance 1660-1800. Eds. Cordner, Michael and Peter Holland. Redefining British Theatre History Series. General Editor: Peter Holland in Association with the Huntington Library. Houndmills and New York: Palgrave Macmillan.

Barbé i Durán, Luis. 2002. Retrato de familia sobre fondo de tréboles. Barcelona: Muchnik.

Bilger, Audrey. 1998. Laughing Feminism: Subversive Comedy in Frances Burney, Maria Edgeworth and Jane Austen. Detroit: Wayne State UP.

Burroughs, Catherine B. 2000. Women in British Romantic Theatre: Drama, Performance and Society 17901840. Cambridge: CUP.

Butler, Marilyn.1972. Maria Edgeworth: A Literary Biography. Oxford: Clarendon Press.

.2004. "Edgeworth, the United Irishmen, and 'More Intelligent Treason". An Uncomfortable Authority: Maria Edgeworth and her Contexts. Eds. Heidi Kauffman and Chris Fauske. Newark: University of Delaware Press. 33-61.

Chisholm, Kate. 1998. Fanny Burney: Her Life 1752-1840. London: Chatto and Windus.

Connolly, Claire. 1995. Gender, Nation and Ireland in the Early Novels of Maria Edgeworth and Lady Morgan. Cardiff: University of Wales.

Cronin, John. 1980. The Anglo-Irish Novel. Vol I. Belfast: Apletree Press.

Doody, Margaret Anne.1988. Frances Burney: the Life in the Works. Cambridge: Cambridge University Press. 
Edgeworth, Maria. 1817. Comic Dramas, in Three Acts.42London: R. Hunter.

1994 (1801). Belinda. Ed. Kathryn J. Kirkpatrick. Oxford UP: Oxford and New York.

1999-2003 (1798). Whim for Whim. The Novels and Selected Works of Maria Edgeworth. General editor Marilyn Butler. Vol 12. Ed. Elizabeth Eger, Clíona O’Gallchoir and Marilyn Butler. London: Pickering and Chatto.

2000 (1812). El absentista. Trans. M. Salís and A. Canosa. Barcelona: Alba Editorial.

2004 (1800). El castillo de Rackrent. Trans. Betty Curtis. Barcelona: Littera Books, S.L.

Fernández Rodríguez, Carmen María. 2008. “Castle Rackrent y sus paratextos en el siglo XX: el caso alemán y francés”. Proceedings from the 31st AEDEAN Conference. Ed. M.J. Lorenzo Modia. A Coruña: Servicio de Publicacións da Universidade da Coruña. 21-30.

.2009. “Leaving Utopia Behind: Maria Edgeworth’s Views of America”. Irish Studies 4. 9-20.

.2010a. "Edgeworth in Germany: Recovering Schloss Rackrent 1802”. The Wake of the Tiger: Irish Studies in the Twentieth-First Century. Eds. David Clark and Rubén Jarazo Álvarez. Weston Florida: Netbiblo. 69-79.

2010b. "Blurring the Lines Between the Nations: Slippery Identities in Maria Edgeworth’s Patronage (1814) and Ormond (1817)”. Op.Cit. 12. 277-88

Gallagher, Catherine. 1994. Nobody's Story: The Vanishing Acts of Women Writers in the Marketplace 16701820. Oxford: Clarendon Press.

González Casademont, Rosa M. 1994. “Castle Rackrent (1800) de Maria Edgeworth. ¿La primera novela irlandesa?” Mujeres y literatura. Eds. Angles Carabí and Marta Segarra. Barcelona: PPU. 59-70.

Harvey, Alison. 2006. “West Indian Obeah and English 'Obee': Race, Feminity and Questions of Colonial Consolidation in Maria Edgeworth’s Belinda”. New Essays on Maria Edgeworth. Aldershot: Ashgate. 129.

Kauffman, Heidi y Chris Fauske, eds. 2004. An Uncomfortable Authority: Maria Edgeworth and her Contexts. Newark: University of Delaware Press.

Kilfeather, Siobhán Marie. 1989. "Strangers at Home”: Political Fictions by Women in Eighteenth-century Ireland. Diss. October 1989. Princeton University. Ann Arbour: UMI.

Kowaleski-Wallace, Elizabeth.1991. Their Fathers' Daughters: Hannah Moore, Maria Edgeworth and Patriarchal Complicity. New York and Oxford: Oxford UP.

Loftis, John. 1977. Sheridan and the Drama of Georgian England. Cambridge, Massachusetts: Harvard UP.

Maguire, W.A. 1996. “Castle Nugent and Castle Rackrent: Fact and Fiction in Maria Edgeworth”. EighteenthCentury Ireland 11. 146-159.

McCann, Andrew. 1996. "Conjugal Love and the Enlightenment Subject: the Colonial Context of Non-Identity in Maria Edgeworth’s Belinda”. Novel 30.1. 56-77.

McLoughlin, Tim. 2002. "Settler Instability: Edgeworth's Irish Novels and Settler Writing from Zimbabwe”. Irish and Postcolonial Wrtings. Eds. Glen Hooper and Colin Graham. Houndmills and New York: Palgrave Macmillan. 89-108.

Morash, Christopher. A History of Irish Theatre 1601-2000. Cambridge: CUP, 2002.

Nash, Julie, ed. 2006. New Essays on Maria Edgeworth. Aldershot: Ashgate.

O'Gallchoir, Clíona. 1998. Maria Edgeworth and the Rise of National Literature. Doctoral Dissertation. Cambridge University, 1998. Ann Arbour: UMI.

O'Shaughnessy, D. 1999. “Ambivalence in Castle Rackrent”. The Canadian Journal of Irish Studies 25. 1-2. 427-40.

Perera, Suvendrini. 1991. Reaches of Empire: The English Novel from Edgeworth to Dickens. Ed. Suvendrini Perera. New York: Columbia UP.

Poovey, Mary, 1984. The Proper Lady and the Woman Writer: Ideology as Style in the Works of Mary Wollstonecraft, Mary Shelley and Jane Austen. Chicago and London: The University of Chicago Press.

Rev. of Comic Dramas. 1817. The British Critic 7. 506-14.

Slade, Bertha Coolidge. 1937. Maria Edgeworth 1767-1849: A Bibliographical Tribute. London: Constable Publishers. 
Tracy, Robert. 1985. “Maria Edgeworth and Lady43Morgan: Legality versus Legitimacy”. Nineteenth Century Fiction 40.1. 1-22.

Wheatley, Christopher J. 1995. Beneath Iërne's Banners: Irish Protestant Drama of the Restoration and Eighteenth Century. Notre Dame, Indiana: University of Notre Dame Press.

Received 19 December 2011 Last version 25 February 2012

Carmen María Fernández-Rodríguez holds a $\mathrm{PhD}$ in English Philology (University of A Coruña). Her dissertation thesis analysed Maria Edgeworth's and Frances Burney's narrative works. At present she is a teacher at the English Department of the Official School of Languages in Santiago de Compostela (Spain). She has published several articles in the field of translation and cultural studies and is currently working on Maria Edgeworth's reception and translation on the Continent and on the oeuvre of Sarah Harriet Burney, Frances Burney's half-sister. 